\title{
PROBLEMS OF MANAGING SEMI-ACTIVE RECORDS IN INSTITUTIONS OF HIGHER LEARNING: THE CASE OF UNIVERSITY OF DAR ES SALAAM.
}

\section{Evans Wema}

\section{Abstract}

This paper discuses problems of managing university records by paying much attention to difficulties in managing semi-current records which, according to records management processes, are supposed to be kept in a records center. Due to absence of this facility, the congested and poorly organized records in university registries in both, the main registry and departmental ones, organizing, storing and retrieving information from these records is a serious problem. The paper suggests several ways of solving the problem. One being that the university establishes a records center whose main purpose will be to house inactive or semi-active records. By so doing, these records will be easily retrieved for occasional use or be kept there pending their ultimate destruction or transfer to archival storage. Another way is by establishing an effective records management program that will provide effective ways of managing records throughout their life cycle. Several examples of records centers in other universities and how efficiently they work have been highlighted.

\section{Introduction}

Evans (1974: 415) defines records management as "that area of general administration management concerned with achieving economy and efficiency in the creation, use, maintenance and disposition of records. Mangara (1997:4) observes that records are so important in any organization, they influence in the same way, the activities of every employee. Those who work in the office daily are especially concerned with records in some capacity. No office worker in any organization will perform his/her duties completely, without handling records.

Choongo (1998: 77-87) observed the importance of keeping records in Universities. He shows that, it is for this reason that records system in Universities is so important that, if no proper care is taken to manage the memory of what has been done and what the University intends to do, then those records can be lost to present and future generations.

According to Gill (1993: 4) records pass through stages, which are referred to as life cycle of records. The first phase of the records cycle deals with the creation of the record. Creation may be in a variety of media including

Evans Wema is Assistant Librarian at the University of Dar es Salaam Library and a Lecturer at the Department of Information Studies. 
paper, electronic, video microfilm etc. The second stage begins from the time the record is received in the organization. At this stage the document is classified and filed to ensure easy retrieval and accessibility. The document then becomes active. Then the record passes to a third stage when the record is no longer required for day to day operations of the institution. The final stage is that of disposition when a decision has to be made on whether to retain a record for historical and research purposes or it should be disposed of (Penn, 1983: 5). The life cycle approach in records management as Newton (1988: 7) argues is of vital importance to understand that records management is concerned with the entire life cycle as they progress through the basic system stages.

\section{Semi-active Records}

Semi-active records are records that are not required constantly for current use and need not be maintained in the expensive office space, storage areas, or equipment of the user. Semi-active records still retain primary value to the operational and administrative functions of the originating agency and are stored in inexpensive storage facilities until all primary values have lapsed. Retrieval and reference access to semi-active records shall be less than one reference per cubic foot per month. Since the above situation does not apply to the current state of university records, the University of Dar es Salaam faces several problems as outlined below:

\section{General Problems of Managing Semi-active Records}

Most of these problems are caused by malpractice, which begin when records are in the active stage in registries. Experience has shown that these problems exist in every institution, University of Dar es Salaam not an exemption. This arises as a result of:

- Lack of proper accommodation for records in which case records are dumped on floors, top of cabinets, and sometimes mixed with unusable items. It becomes difficult for registry clerks to identify semi-active records from among the piles of records dumped in registry offices or any place where such records are kept.

- Inadequate filing equipment which leads to mismanagement of files. In some cases there is breakdown of the filing system in registries, which results into uneconomic and inefficient registry operations.

- Lack of trained personnel who are qualified to work as records managers. In addition, there is lack of supervision within an organization and also there is no follow-up after training.

- Absence of, and failure to implement disposal plans or schedules, which create a mammoth growth of records in various departments, the majority of which are not valuable. These records continue occupying office space and equipment. 
Some of the above problems have been noted in other universities in Africa as observed by Afolasi (1996: 49) who studied problems of records management in two universities of Ahmadu and Ibadan where he found out problems associated with inadequate storage area for records and inefficient retrieval systems.

\section{Records Management Program}

Records Management Program and its Importance in an Organization

For any records management system to function efficiently there has to be a records management program for the organization. This program strives to achieve an orderly and efficient flow of information throughout the organization. Records management programs have a direct bearing on whether an organization has an effective records management program or not. The need to introduce records management programs in business or in an organization is even greater today as a result of the use of modern technology which lead to paperwork explosion. Therefore information should be properly collected and stored for easy retrieval without wasting much time and space (Gill, 1993: 3).

In short, an effective records management program consists of:

- Developing policies and procedures for managing records and information;

- Implementing filing and indexing systems and tools;

- Conducting an inventory of records;

- Establishing and following records retention schedules;

- Identifying and using technology appropriately to create, store and retrieve materials;

- Storing inactive records in a cost-effective and secure location;

- Destroying obsolete records in a timely and systematic manner and documenting their destruction;

- Identifying and preserving vital records (those that are essential to conducting and continuing business operations);

- Identifying and preserving archival (historic, permanent) records;

- Developing a disaster preparedness plan to protect and recover records in the event of a disaster;

- Developing forms to maintain efficient operations.

\section{Records Management Program at the University of Dar es Salaam}

The University of Dar es Salaam has embarked on the program called Institutional Transformation Programme. This is a long term (1993-2008) program which is aimed at facilitating the UDSM to operate in 21 st century with a clear vision and objectives. One of the objectives of this program is to contribute to the advancement, transmission and preservation of all forms of 
knowledge in line with internationally accepted standards of academic excellence. This is in line with the proposal to establish the UDSM archival policy and procedures.

The University of Dar es Salaam has not had an archival policy since its establishment in 1970. The consequences of this have been difficulties in locating required records, high storage costs, loss of valuable records and time in locating records. In attempting to solve this problem, the Chief Academic Officer (CACO) appointed a team of five members of staff on $8^{\text {th }}$ October 2002 to prepare a University-wide archival policy to guide the University in identifying and preserving archival records. The proposed University-wide policy provides a set of guidelines and procedures for the management of archival activities. The policy states, among other things, the ownership of the University archival records, accessibility, preservation methods (i.e. both in print and electronic media), criteria for selection of records for archiving and determination of type of archival records to be preserved. A survey was conducted in 16 University faculties, institutes and college offices to determine whether there was a need to have a Universitywide archival policy. The answers showed that all were in favour of such a policy (University of Dar es Salaam: 2003). The need to have such policies and procedures is also observed by the Records and Archives Management Act No.3 of 2002, which requires all public institutions in Tanzania to manage their own records where it is clearly stated in Part III, Section 9 of the Act that:

Heads of public offices shall be responsible for creating and maintaining adequate documentation of the functions and activities of their respective public offices through the establishment of good records-keeping practices (Records and Archives Management Act, 2002).

The first draft for this policy proposal was submitted to CACO on $15^{\text {th }}$ November 2002, there after, it was circulated to stake holders, i.e. College Principals, Deans, Directors, students and other University staff members so as to generate information, that could facilitate the completion of University archival policy.

Lack of archival policies is not only within the University of Dar es Salaam. In Tanzania there are no archival policies either at national or institutional level. The approach in Tanzania has been first, to develop a legislation (Archival Act - now repealed by Archives Management Act No. 3 (2002) and secondly develop a policy. To-date the envisaged national policy has yet to be developed. 


\section{Records Centers in Universities The Role of Record Centers in Managing Semi-active Records}

The most effective way of managing semi-active records is by the use of record centers. A Records Center is a facility for the low-cost, short-term storage and processing of records pending their disposal or transfer to the Archives.

It involves establishing or managing a warehouse type repository or storage facility, or using a provider of such a service, where inactive or semiactive records are housed and from which they can be retrieved pending their ultimate destruction or transfer to archival storage. When the organization's records become inactive, they are appraised and transferred to a records center. They are then processed and kept in an archival manner. The creating office is issued with a transfer list of the files it has deposited. Records transferred are treated as confidential and no one can get access to them without the written authority of the depositing department. These records cannot be made accessible to the public until the elapse of specified time, unless stated otherwise by the authorities,

\section{According to Mabbs (1984: 78):}

the aims of the records center are to prevent the unnecessary use of space as offices for public departments and other bodies for the storage of records which are no longer in active use; prevent the use of repositories for the storage of papers which retain sufficient administrative use and yet have not reached the age at which they can be made available for public inspection; ensure that records which are no longer in active use are subjected to effective procedures for the identification of those which can be destroyed after agreed retention periods and; provide service for making documents available to various organizations to which they belong.

Ricks (1988) in addition to the above, argues that a records center helps to maintain total security over the company's records. It establishes control to ensure continuous flow of records from offices to low-cost storage.

The value of a records center to an organization is therefore beyond question. Records center not only provides viable and economical alternative to micragraphic storage, expensive office retention or premature destruction of records but also saves money on staff and office equipment (Smith. 1989: 70). An example of this can be drawn from Ohio Montgomery County where the records center completed its third year of operation (i.e. 1983 - 1986) with almost 19,000 cubic feet, which was capable of housing about 50 million documents, which were previously housed in expensive office space using expensive equipment. This was equal to 1,800 file cabinets occupying over 15,000 square feet of prime space in newer buildings. This saved about US $\$$ 500,000 (including operational costs) (Waegemann. 1983). 
The Government Records Repository in Australia meets the records storage needs of public sector bodies in New South Wales, including Government agencies, local councils, public hospitals and universities. The Repository is a secure, modern, centralized records center, providing for the special storage requirements of records, their retrieval, and ultimately their disposal, using the most economic methods. The Repository complex also has facilities for the public to use State archives.

Record centers also serve as reference centers. People come to request for information found in semi-active or inactive forms and record managers, by using properly fixed retrieval tools, would retrieve it so as to serve the clients. Records center may be institutionally owned or commercial. In the case of Tanzania, there has not been any known records center, which is for commercial basis, hence emphasis should be put on institutionally owned records centers. In this case, consideration should be made of its location where semi-active records are to be stored. Most convenient location may be within the institution itself where a special building may be chosen (or a space within a building such as basement or attic spaces). The use of these areas is dependent on proper heating, lighting, humidity controls and floor load capacity, as well as the amount of usable space. Usable space depends on ceiling height, minimum obstructions and odd shaped spaces. Planning for a records center should consider future needs as wetl as current space pressures.

If space capable of being converted to a records center on a cost-effective basis is available, the organization (such as the University of Dar es Salaam) may choose an onsite records center. Onsite location offers many advantages to the organization. It allows for ease of access of information. Also a delivery system to get the information from one location to another is not needed. It is easy to have total control over the organization's records. The volume of records and kinds of records are determined by records inventory report that identifies all of the organizational records classified as semi-active or inactive. The space required to house records should be determined by the method in which the records are to be stored. Most record centers store records in cartoons which are then placed on steel shelving. Mobile shelves can also be used in the record centers. This type of shelving allows for a greater density of records to be stored in the same area.

Therefore a record center has to be designed so as to fulfill the following:

- To reduce the need for storage equipment thus creating ample space;

- To establish control to ensure a continuous flow of records from offices to low-cost storage;

- To reduce the total volume of records held in offices and storage areas;

- To establish an efficient retrieval system. 


\section{University Record Centers}

Several Universities in the world have embarked on the records management program for developing guidelines ensuring that records created at the universities are well managèd. The North-eastern University in the US, through its Archives and special collections department, has developed a records management program whose emphasis is on conducting record surveys, retention schedules, transferring university semi-current records to the record centers or University archives. The Clemson University for example, is required to make, preserve and safeguard records (regardless of media or characteristics) that document University functions, policies, procedures and decisions and those that protect the legal and financial rights of the University and the State of South Carolina. To ensure that records of the University are properly managed, the Clemson University Records Management Unit runs a records center. Apart from serving the university community in preserving its semi-current records, the center also reserves 6,500 boxes for the purpose of serving the public in storing records for the cost of $\$ 2.40 /$ per box per year (.20\& per box per month).

The University Records Centre (URC) at University of Pennsylvania is administered and operated by the University Archives. The primary function of the URC is to store semi-active records of the University. The Records Centre has space for approximately 4,000 record storage boxes (standard 1.5 cu. ft. for the boxes). Each shelf location space has been assigned a unique location number which is recorded in a URC location database. From the database URC staff is able to determine if a location space is free or occupied by a records storage box. If a location space is occupied the database also records the contents of the box stored at that location, the department or faculty that owns the box, the applicable Records Retention Schedule and Disposal Authority number and the disposal date and final disposition of the records. In addition to semi-active storage the URC also provides a file retrieval service. From detailed box location lists produced from the locations database, users of the Centre are able to phone-in or email specific file requests to URC staff. Files are retrieved and delivered to offices by the URC file courier or may be picked-up at the Archives office.

In Africa, several universities have established record centers that preserve semi-current records from different departments and even outside the university. The Central Records Office at University of Witwatersrand in South Africa is responsible for:

providing records-keeping advice to university departments, for developing systems for effective control of documents, files and records in all formats, and for implementing information and records management policies, standards, and procedures. This includes responsibility for the survey, inventory, description, appraisal, disposition, and accession of official university records. It covers both records designated for archival retention and records of temporary value ${ }^{1}$. 


\section{Current State of Record-keeping System at the University of Dar es Salaam}

Like any other institution, the University of Dar es Salaam is a place where records are created through forms, correspondences and instructions. Records control activities such as registration, classification, indexing and tracing are only applied to current records. The most crucial issue at the University is on how to maintain semi-active records. For many years, semi-active records have been stored on file cabinets, tables, shelves and sometimes on the floor. The University central registry keeps both active and semi-active records in the same office due to lack of storage facility for semi-active records. It becomes quite difficult for a registry clerk to access information from these records. Access to these records is made difficult due to the nature of their storage, since most of them are stored in places where files are so overcrowded thus preventing direct access to them. According to the Australian Standards:

"managing access to records is concerned with making records accessible and useable to record users within and outside the organization."

With regard to the above statement, the University faces a problem of poor management of semi-active and archival records.

Currently the University does not have any warehouse or storage facility where semi-active records can be kept. Initially, the University used to store most of its records at a place called BRALUP (Bureau of Resource Assessment and Land Use Planning) now called Institute of Resources Assessment, but this place is no longer used for that purpose. Currently, the University is automating some of its records like students' records by ARIELS program, and some information is uploaded on the University website. With an increase to the use of computers, a lot of records are created electronically in University offices, departments and institutes. Some of these records are stored on disk drives and CD-ROMs but there is no clear policy as to how semicurrent electronic records should be handled. This problem is made much more serious since the University's archival policy is not yet effected because, as stated in the previous sections, this policy is at a proposal stage. Once the policy is finally put into use, it will act as a tool to aid the University authorities in making decisions on all matters related to storage, maintenance and disposition of records.

\section{Suggestions to Problems of Managing Semi-active Records at the University of Dar es Salaam}

In order for the University to have a well-coordinated records management program, it has to establish a records center where semi-active records should be kept. To ensure the above, the following can be done: 
- The University should find concrete solutions to specific university-related records management problems such as lack of space to store records, unskilled manpower, lack of storage equipment and many others, as already observed by consultants and other experts who, from time to time, have made similar recommendations;

- The University should introduce a standardized University classification and filing system in every unit. This should be revised and updated to adequately reflect the functions and activities of offices at the University. The system will assist in information retrieval and identify records that are no longer needed to stay in registries any further;

- The University should draw up a records retention schedule and promote its adoption throughout the institution. This will assist records managers in making decisions on records which are to be disposed of from the registries;

- The University should provide training to employees who perform records management duties. Training of staff is one way of motivation through maintaining high productivity;

- There should be top management support in terms of staff training, accommodation, equipment and promotions. Management should take every interest in record management since record managers are given regular guidance from senior officers;

- Record managers should conduct periodic record surveys for the purpose of determining the physical location of all records of the University in its various departments. The survey would also assist in identifying the nature, quality and purpose of the organization's records. Other purposes of records survey are: to assist in advising on disposal procedures of non-current records in the departments; examining the conditions under which records are kept and advise on proper records management and registry systems in relation to current, semi-active and non-current records.

It is therefore proposed that the University reinstates the facility which was at the Institute of Resources Assessment (BRALUP) or find another building where semi-active records can be stored. The physical layout of this facility would take into consideration a plan with the following basic areas:

- Records storage area: This should be a place where records will be stored. There should be enough space to allow for movement of people and should be well lit. If possible, records should be stored in cartoons and placed on steel shelves;

- Administrative area: this area will include other areas such as reference area, office for records managers and clerks, receiving, preparation and disposition areas; 
- Reference area: this should be efficient, comfortable place for users and should include tables and chairs, photocopier (whenever available) and other necessary materials;

- Receiving area: this is the area where records will be received when they are brought into the center;

- Preparation area: this is a place where record personnel prepare the incoming records for shelving and storage;

- Disposition area: this is a place where records are disposed from the center. It should not be near the receiving area.

It is expected that the University of Dar es Salaam will also develop a records management program for the purpose of managing its records in adherence to the Records and Archives Management Act of 2002, issued by the Tanzania government.

\section{Footnotes}

Central Records Office, University of Witwatersrand (South Africa): http://www.wits.ac.za/cro/general info.htm (Accessed 08/03/2003)

Australian Standards for Records Management: http://www.records.nsw.gov.au/publicsector/rk/whatisrm/what_is_r m-03.htm $\#$ P149 13840

\section{References}

California State Records Management Act 1997 (Gov. Code, sections 1474014775).

Choongo, M.W. (1998). "Justification for setting up an archive at the University of Zambia: Problems \& Prospects", Africa Journal of Library, Archives \& Information Science, Vol. 8(2): $77-87$.

Evans, F. B., R. H. Lytle, (1975). "Management of archives and manuscript collections for librarians". Drexel Library Quarterly, vol. 11 no. 1 p. $400-415$

Gill, S.L. (1993). File Management and Information Retrieval System; a Manual for Managers and Technicians. Englewood: Libraries Unlimited Inc: 34 .

Mabbs, A.W. (1984). Reader in modern archive administration and records management (English edition). 14 Acorn Lane Cuffley Hertfordshire.

Magara. E. (1978). Planning and management Registries: A strategic Approach. Makerere University. Kampala. 
Newton, S.C., (1989). "Strategic information management - concept and reality". Records Management Journal. Vol. 1, no. 4

Penn, I. A. (1989). Records Management Handbook. Brookfield: Ashgate Publishing Company Ltd.

University of Dar es Salaam (2003) Proposal for the establishment of the UDSM Archival Policy and Procedures. Unpublished paper.

Tanzania. United Republic. (2002) Records and Archives Management Act (2002).

Smith, K.J. (1989). "The storage and control of paper during the semi-active phase: the government's perspective". Records Management Journal. Vol. 1, no. 2. P68-78

Waegemann, C. Peter. (1983). Handbook of record storage and space management. Connecticut. Westport. 